\title{
Pattern, Symbolism and Role of Candle Holder in Lao People's Democratic Republic
}

\author{
${ }^{1}$ Chaiborpit Ponsri, ${ }^{1}$ Burin Plengdeesakul and ${ }^{2}$ Tik Seanboon \\ ${ }^{1}$ Faculty of Fine and Applied Arts, Khon Kaen University, \\ 123 Moo 16 Nai Muang Sub-District, Muang District, 40002 Khon Kaen Province, Thailand \\ ${ }^{2}$ Faculty of Applied Arts and Architecture, Khon Kaen University, 85 Muang Srikai Sub-District, \\ Warinchamrap District, 34190 Ubonratchathani Province, Thailand
}

\begin{abstract}
The research of pattern, symbolism and role of candle holder in Lao people's Democratic Republic was aimed to study, the background of candle holder, pattern and symbolism and role of candle holder in Lao's people Democratic Republic. The target group was located in Luang Prabang, Vientiane and Champasak by using research tools which consisted of survey, observe and interview to analyze with historical theory, semiology theory, role theory, architectural and composition concept and presented by descriptive analysis. The study of candle holder's background in Lao People's Democratic Republic (Lao PDR) was found that the history of candle holder was initiated in Lan Xang era which considered as the formation and symbolism of traditional Lao candle holder. In the colonial era, the candle holder was conceptualized from Buddhism and exotic art. In the colonial era, Buddhism was ignored due to French policy, later it was restored together with Buddhist art but after restoration, socialism concept was spread out and caused to conflict with feudal system and led to the clearance of feudal system and Buddhist art. At present, the candle holder was re-created with cultural diversity of Lao society in the present. The pattern and symbolism of candle holder in Lao PDR was indicated that pattern means structure and element with the identity of "Naga". The symbolism was found that it related to Buddhism belief and cosmological ideas and also being communicative tools for historical phenomenon aroused political ideology to Lao people. In the past, candle holder has played a role as tool and was measurement of area in important Buddhism rituals, at present candle holder still was used as the same role. At the past, the role of candle holder in Lao cultural society was found that the candle holder was the reflection of Lao society, Social status, faithfulness of Buddhism, the precious Buddhist art, Political communication tools and representative of the feudal system for current, it was played the role as a reflection of Lao society, social status, faithfulness of Buddhism, encouragement of Buddhist art and monk and precious cultural heritage.
\end{abstract}

Key words: Pattern, symbolism, role, candle holder, Lao people's democratic, fiaithfulness

\section{INTRODUCTION}

Lao people's democratic has a long history. At the beginning of the formation of Chao Fah Ngum Kingdom and received Buddhism to integrate with the original beliefs and then became to their identity until the present (Pothisan, 2015), resulted to traditional, cultural, various art work patterns in each ages. The main art work was appeared in religious building in each temple. It also appeared in various ceremonial instruments included Buddhist art which was used for traditional rituals, belief and Heets in various patterns, the patterns were reflected meticulousness and integrated of symbolism in each local and became their Buddhist art (Saenboon, 2012). Lao Buddhist art was kept traditional and contemporary style of Lan Na, Sukhothai and Ayutthaya. It also got influenced from Buddhism which changed the patterns as the result to development of art following Lao ideals and has appeared until the present (Rodboon, 2002).

Especially, the candle holder which used in an important Buddhism ritual. The candle holder was used as the candle's base to worship the importance rite, therefore, the reason to create the candle holder (Bannalit Khatiyalat: Interview, 2017)

The patterns and symbolism of candle holder in Lao PDR recorded by Loius De Game the Frenchman who arrived Vientiane in 1867 and Garnier between 1870-1871 was mentioned about the candle holder patterns in Srisaket temple that "The patterns are unique and meaningful or interesting symbolism". In addition, De Laporte painted the candle holder of Srisaket temple to publish in global journals, after that Henry Parmentier who

Corresponding Author: Chaiborpit Ponsri, Faculty of Fine and Applied Arts, Khon Kaen University, 123 Moo 16 Nai Muang Sub-District, Muang District, 40002 Khon Kaen Province, Thailand 
studied Buddhist art had restated the important of patterns and symbolism of candle holder in Srisaket temple that " The heads of Naga were elegant and look being alive as if flying in the sky" Marchal also mentioned about the candle holder in Srisaket temple that it's the most beautiful ones and showing skill of Lan Xang wood-sculpture (Ngaosivat and Nghoasriwattana, 2010). Furthermore, the role of candle holder still yet systematical study, especially, candle holder role for Buddhism and cultural society of Lao in each era.

As the reasons and important of the candle holder, it began to the study of pattern, symbolism and role of candle holder in Lao People's Democratic Republic to emphasis on the history of pattern, symbolism and role of candle holder in Lao people's Democratic Republic to initiate new knowledge management.

\section{Research objectives:}

- To study the background of candle holder in Lao PDR

- To study pattern and symbolism of candle holder in Lao PDR

- To study role of candle holder in Lao PDR

\section{MATERIALS AND METHODS}

Target is Haw Tien (candle holder) in Sim or abbey, ubosot, religious building or temple in Lao PDR in 3 districts; Luang Prabang, Vientiane and Champasak. The target have to related to the king, royal lineage, courtier, Seignior in the past and associated with political history in Lao PDR included museum or place for preserving candle holder with permission of the owner to study. Target-Person group in this research, the researcher selected a specific sample as follows:

- Key-performance group 19 peoples consisted of 6 governmental officers, 6 academics and 7 community wisdoms

- Pragmatic group 2 candle holder makers in Luang prabang and vientiane district

- $\quad$ Related group 23 people which 22 people involved with religion and 1 is candle holder leader

Research tools were used survey, unstructured observation and structured interviews and unstructured interviews. Data collection was collected from documents and field-data from survey, unstructured observation, structured interviews and unstructured interviews from public, private and community groups to cover the research objectives. Data analysis, the researcher analyzed data from documents and field data from survey, observation and interview then transcribed, sorted, categorized and summarized content with objectives. Dezin's Data Triangulation (1970) was used to determine the validity of the data. After studying the data, the results of the study were categorized according to the objectives.

Data analysis when got the results of the investigation. The researcher took the result in aspect of historical background to analysis with Franz Boas's historical theory. The results of patterns study were analyzed by architectural concepts of Wiroj Srisuro with composition of Hermann F. Branz. The symbolism was analyzed with symbolic theory of Laurent Bass. The results of roles study were analyzed by Moreno's theory to create new knowledge management of research. Presentation, the researcher presented result by report writing with descriptive analysis combined with photos and line drawings with creates charts or tables to describe conclusion of data analysis.

\section{RESULTS AND DISCUSSION}

The study of candle holder in Lao PDR got result as follows history of candle holder in Lao PDR was found that it was categorized into 4 eras.

Kingdom of Lan Xang era: It is formation or the beginning era of candle holder. The candle holder patterns had defined or developed included concept or tradition of creating traditional candle holder. It might adopted art from each art school to combine and adapt to created traditional candle holder.

Dependent era: An second development of candle holder which received Buddhism concept and art from neighboring kingdom to adapt in candle holder.

Colonial era: Divided into 3 periods: early colonial period was the first time that France began to settle exploitation in Lao and oppresses heavy labor with few wages result in difficult time in Lao. Moreover, they brought the system of education, culture and social class from France to dominate Lao people result in people are focus only themselves and ignore to maintain Buddhism and caused to anti-French regulation spread throughout the Lan Xang Kingdom. Middle Colonial period, there was a restoration, survey and reconstruction of the arts, architecture, Buddhist art, Buddhist rituals tool, including candle holder as a database in the arts of various branches of 


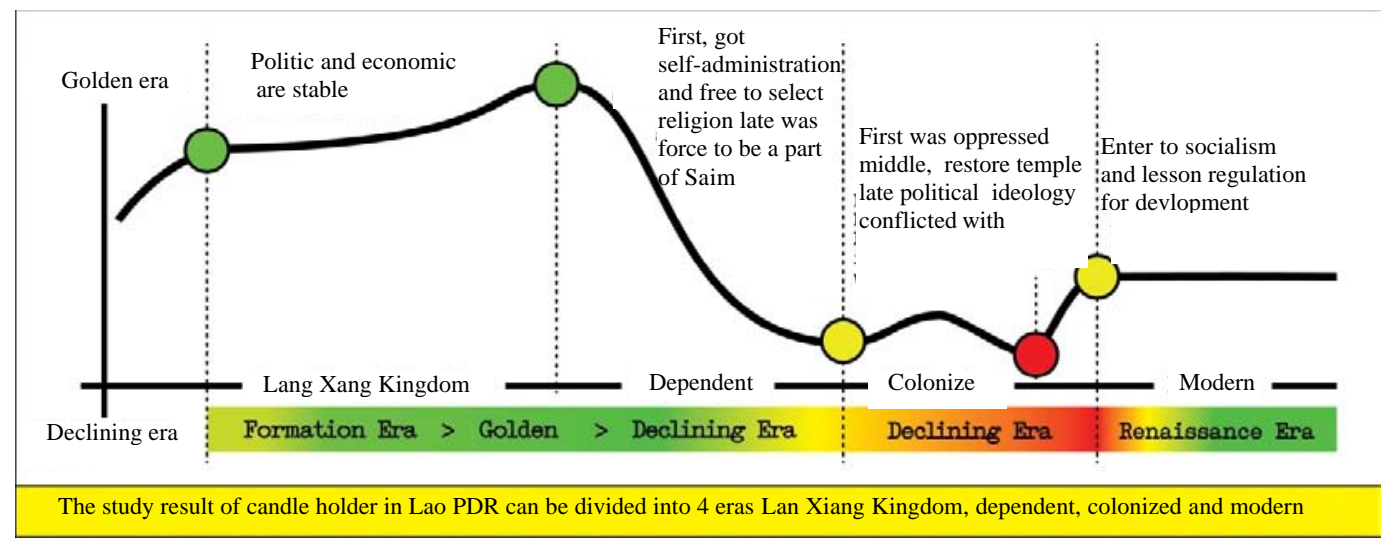

Fig. 1: Age-classification for candle holder in Lao PDR

Laos because of the need to reduce trend of anti-French regulation through the restoration of Buddhism as a center of the mind of Lao people, it was considered as golden age of art renaissance in Laos. Late colonial period, the concept of political ideology and socialist ideology was in conflict with the old regime of feudalism and then entered to the civil war of Laos between feudalism and political ideology.

Modern era was a reflection of the return of candle holder to current society. With difference factors and reasons in creating candle holder in the past, it was the most important to create candle holder in Lao cultural society is faithfulness in Buddhism and value of Buddhist art in candle holder.

Symbolism of candle holder in Lao PDR was divided the results as follows: Patterns of candle holder in Lao PDR are divided into 6 groups, namely, physical characteristics, images, styles, materials, decoration methods and art school (Fig. 1). Patterns, candle holder patterns in Lao PDR is mostly similar, details of the patterns depend on the religious leader, art school, belief in each area.

Physical characteristics, candle holder was symmetrical arranged. The physical structure is divided into 2 groups: the physical group divided into 2 parts: base and body (central). And the physical character separate to 3 parts lotus shape base and animal shape base, body (central) have 3 pillars pattern and 2 channels, 4 pillars pattern and 3 channels and solid patterns. The crests have a single that pattern, group that pattern (Lao Chor Fah pattern) and symbolic pattern (Fig. 2-7).

Image, there are 3 groups: 1.Portrait, i.e., gods, deity, Rahu, 2. Mythical creature, i.e., Naga, makara, capricorn, qilin, elephant, swan, fish and the others, i.e., coiled Naga

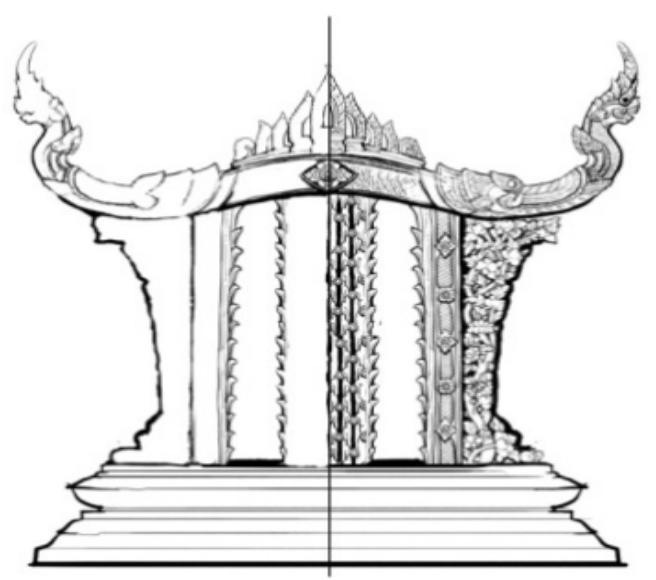

Fig. 2: Line and symmetrical arranged of candle holder

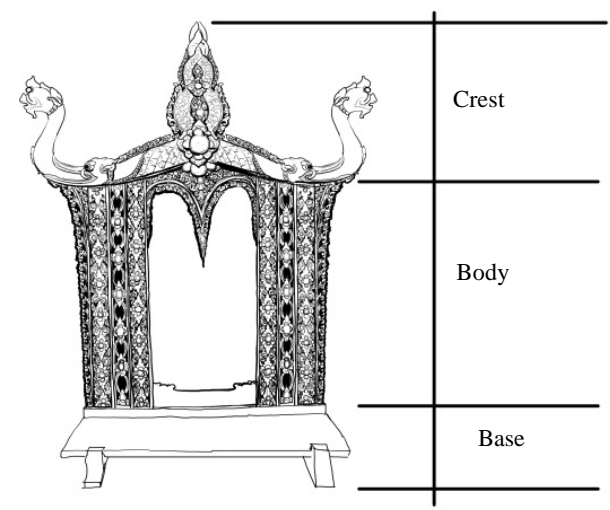

Fig. 3: Line and symmetrical arranged of 3-part candle holder

tail as the crest of that derived from traditional Lao Buddhism which believe in Cosmology concept and Himmapan's creatures. 


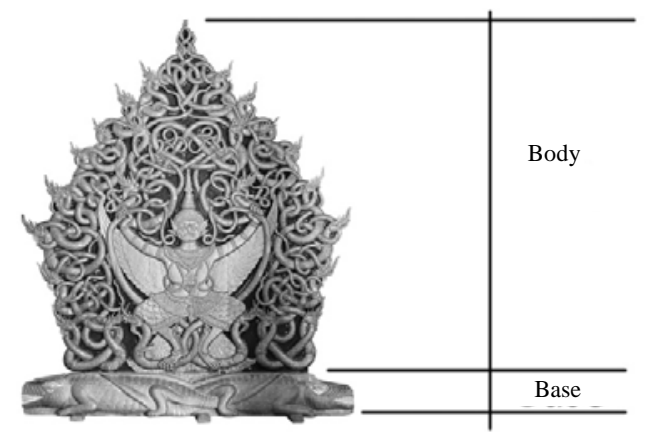

Fig. 4: Line and symmetrical arranged of 2-part candle holder

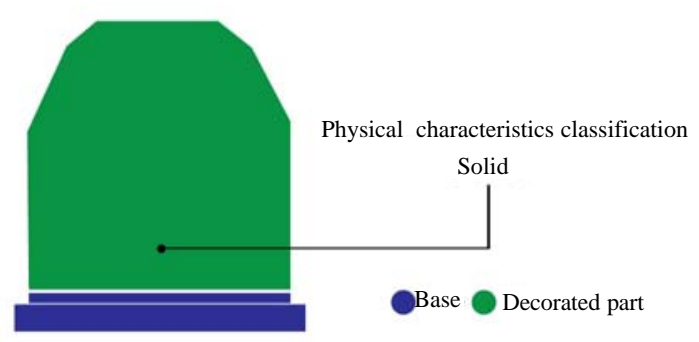

Fig. 5: Solid pattern of candle holder

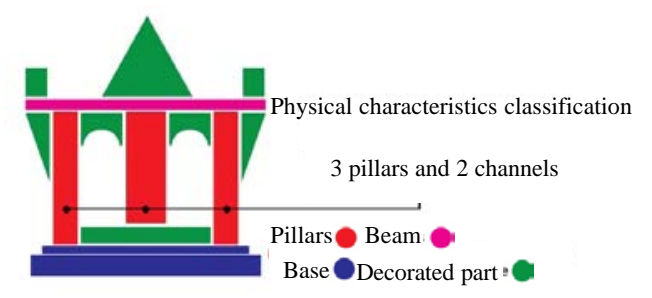

Fig. 6: 3 Pillars and 2 channels pattern of candle holder

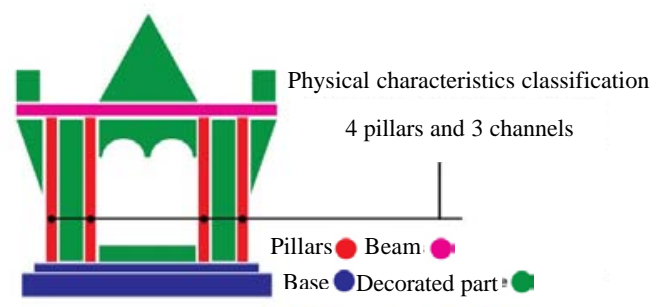

Fig. 7: 4 Pillars and 3 channels pattern of candle holder

Style used to decorate candle holder, i.e., Flora pattern, creeper pattern, coiled creeper pattern, Kanok pattern, Prachamyam pattern, Kra Jung pattern, Wan Laen pattern, Ruang Pheung pattern. These pattern was used in decorate space or pillar for beautiful reason, the details of style have various shapes and characters depend on the skill of art school, religion leader and the creation period of candle holder.
Material was contained 2 groups of materials: Wood which was used as the main structure for the assembly of 3 physical characteristics for strength. In addition, quality wood must be conducive to gouge or carve. And materials for decoration from gold leaf and glass by use gold leaf to make surface smooth and then use color glass as glitter as well as the concept and nobility of religious leader (Fig. 8-10).

Creation and decoration: The creation and decoration processes was divided into 3 steps). The structure by bring wood to form the shape of the candle holder). Gouge or carve wood as skill of art school). Decorate after gouging or carving and gild and then decorate with glass to make it more glitter and beautiful.

Art school, art school who created candle holder reflect patterns, concept, skill and expertise of artisans in each period. In each era will their concept or unique pattern as their identity, so, it can be indicated that candle holder was created from artisans as follows Royal Art School of Luang Prabang in Lan Xang Kingdom era, Royal Art School of Luang Prabang in dependent era, royal art school of Vientiane, Royal Art School of Vientiane in dependent era, royal art school of Muang Phuan in Lan Xang Kingdom, modern art school.

\section{The symbolism of candle holder in Lao PDR is divided into 2 groups}

Direct meaning and significant meaning as follows: Direct meaning physical characteristic, image, style and material is structure or component of traditional Lao candle holder which each part play a role follows discipline or custom of candle holder's creation. Details of image and style include material are reflected to art school, creation period, social status of religious leader and value on Buddhist art.

Significant meaning has 2 groups; Buddhism belief which have physical characteristic, image and style as is structure or component of belief in Buddhism concept of Tri-Bhumi and became to structure or component of traditional Lao candle holder creation and related with exorcise by using Rahu image to represent of sorrow and difficulty and use light from candle in Buddhism to expel sorrow and difficulty. It also has auspicious meaning of the name of wood as delicate decoration which raised candle holder to be valued for worshipping. For Lao historical meaning which reflect to political ideology of religious leader who created candle holder during the dependent and colonial era from foreigner.

Role of candle holder in Lao PDR can be divided into 2 groups as follows: Role of candle holder in Buddhism was 


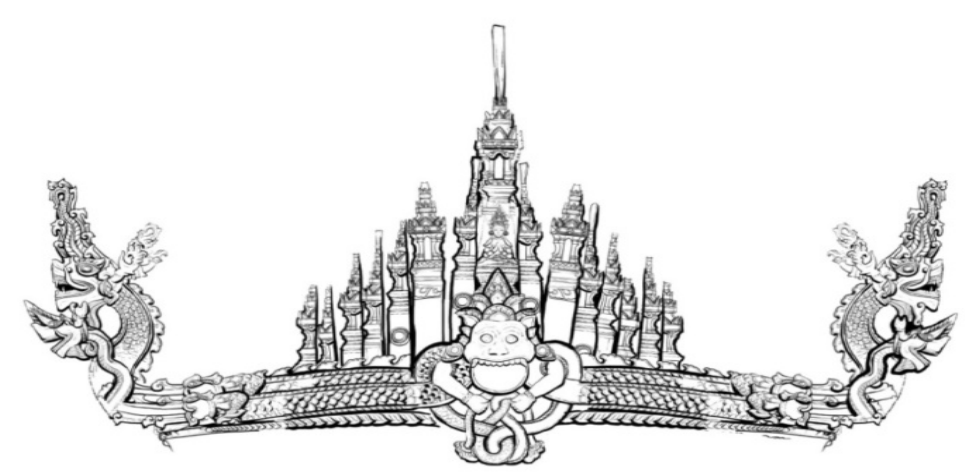

Fig. 8: Naka raise group that (Chor Fah) beam

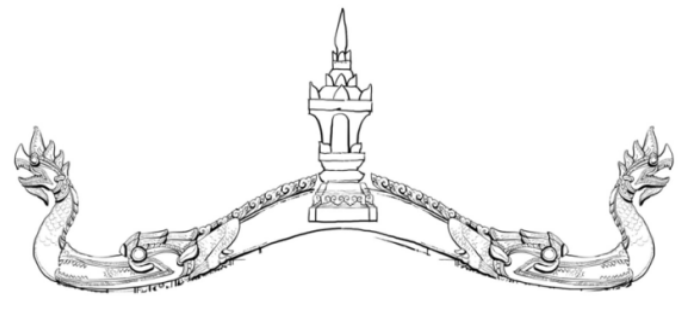

Fig. 9: Naka raise single that beam

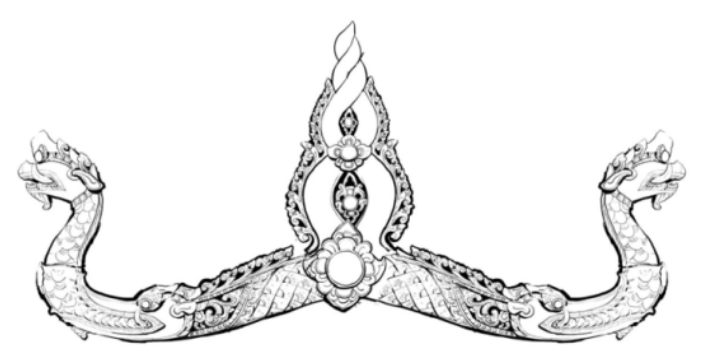

Fig. 10: Naka raise symbolic that beam

found in Lan Xang Kingdom era and dependent era. Candle holder plays a role as a tool and measurement of area in important Buddhist rituals and used for exorcise or fulfil the vow as well as Buddhist Lao art which indicates the dignity of temple. In the colonial period, candle holder's role in Buddhism has 2 periods the early colonial period, candle holder was a valuable Buddhist art and was used as a communication tool for the political movement through the Lao Buddhist art. In late colonial period, the role of the candle holder began to decline due to Lao people have adopted socialist ideals and ideologies. And in modern period, the role of candle holder is also used in Buddhist rituals, however, owning to the monk lacked the knowledge and understanding of it, therefore, it is not much widespread. It also expresses the reflection of the dependence on each other of art work associated with Buddhism with the monk and novice in Luang Prabang.
Role of candle holder in Lao cultural society: In Lan Xang Kingdom candle holder reflects prosperity of society condition, social status, faithfulness of Buddhism and leader. In dependent era, the role of candle holder was changed by Lao society. In the early dependent period, candle holder still remain a similar role to Lan Xang Kingdom. It has changed the role of the late dependent period by adopting concept of Buddhism from Siam combined with original concept of Lan Xang into a unique concept of the Buddhism at this time. And also found that the influence of fine arts from Siam was adapted to Laos Lan Xang art. In the colonial era, candle holder was divided into 3 periods: early colonial period, candle holder was valuable Buddhist art as heritage of art in Lan Xang Kingdom. In middle colonial period, candle holder was added role from the past to be communication tool of political regulation event which reflect Lao history and late colonial period, candle holder became to apart of representative of feudal system as the result from conflict of socialist ideology. In modern era, the role of candle holder shows the status of current Lao cultural society which prosperous like in Lan Xang Kingdom. And also shows faithfulness of Lao people toward present Buddhism under cultural diversity and reflects the value of the Lao Buddhist art considered as cultural heritage for Lao people to maintain.

The history of candle holder began in the Lan Xang Kingdom considered as traditional and symbolism formation. In dependent era, the concept of Buddhism and outside art. And the colonial era, considered as the declining of Laos affect to Buddhism ignorance and later it has been restored. Until, the concept of socialism was perceived and result in a clearance of Buddhist arts, Buddhist architecture associated with the feudal system. In modern era, recreation of candle holder with present concept which different form the past. It corresponded with the historical theory of Srisuntisuk (2007), who cited Franz Boas (2006) as "a historical study is necessary to 
know background or factors which affects the present". The study of candle holder history in Lao PDR, the researcher have to throwback to the past to cover the objectives and bring study results to analyze with historical theory to get the result.

The pattern of candle holder in Lao PDR pattern are is structure or composition of traditional Lao candle holder which has their identity in Naga beam pattern as mentioned about patterns of candle holder reflects physical characteristics, image, style, materials, methods of creation and art school as of then was considered as structure or composition of candle holder corresponded with the architectural concept by Srisuro (1993) which divides religious buildings into 3 parts: base part, body part and crest part with decoration which similar to corbel or mainstay and Ruang Phueng. Furthermore, traditional Lao candle holder also contains a unique feature the connection part between body part and crest part is contained image of "Makara emits Naga" which was found in every candle holder. When using the concept of Hermann F. of style and location of this area which defined outstanding part. It was found that the beam of Naga shape is the most outstanding as result of this analysis it was named this traditional Lao candle holder as it identity named "Candle holder Naga shape beam".

The symbolism of candle holder in Lao PDR, the symbolism is related to the belief in Buddhism and the traditional Lao cosmology and was served as a communication tool in order to stimulate political ideology and reflection political phenomenon in Lao. The study of the symbolism of candle holder in Lao PDR is consistent of the theory of symbols by Roland (1967) who defines the meaning analysis into 2 ways direct meaning and significant meaning a direct meaning is the communication of symbolism in the candles holder, it is meaning that most people able to perceive and understand such as Indra, the perception in direct meaning of Indra is god and also Makara emits Naga; perception was given the direct meaning of Makara release Naga. Significant meaning is the transcription of the symbol or symbolism in candle holder with adopt cultural factors in transcription, for example, candle holder, people may worship it as valuable art work more being just ceremonial tool. And group of that in the crest part of candle holder direct meaning is structure of candle holder but in significant meaning it is auspicious place as Sathaborripan mountain" based on the cosmology concept of Laos which is believed "Chor Fah" as sacred place and may be Meru mountain or the place of Indra and the way to heaven.

The role of candle holder in Lao PDR in Buddhism aspect in the past, candle holder is tool or measurement of area for ceremony. At Present, it still remains the role of a valuable Lao ritual and ceremonial tool. In Lao cultural society, it was found that in the past, candle holder has reflected the prosperity, social status and faithfulness towards Buddhism, valuable Buddhist art, Political communication tools and feudal representative. Now a days, candle holder reflects of the prosperity of the country, social status, faithfulness towards Buddhism, and valuable cultural heritage.

Ponsri (2002) has cited Jacob Moreno who discusses the role of theory that "Social organization has a network of roles as a force to initiate role's concepts which have 3 kinds the role of the biological needs is the role that the actor is candle holder but serve needs of the society as valuable Lao Buddhist art in the present. Social context is the role of a person or a candle holder has paid the role according to society's expectations as tool or measurement of area in the ritual for the king. And in the other social context person or candle holder has paid the role to the general expectations of the society as representative of faithfulness of Lao people towards Buddhism of Lao culture society in the present. Furthermore, the role of candle holder is one of the social mechanisms or Buddhist requirements that will make the people of Laos stay together and can create systematically relation with various status and role in each society.

\section{CONCLUSION}

The history of candle holder in Lao PDR was shown it has divided into 4 eras Lan Xang Kingdom was the formation period of development and symbolism until turn into identity of Lan Xang pattern. Candle holder was supported from religious leader group. Royal lineage, Seignior, upper-class merchants and ordinary people. In dependent era, It is the second, consecutive of the development of candle holder from Buddhism and patterns outside the kingdom to apply but still maintain the patterns and symbolism of Lan Xang era until, the early colonial period considered as the declining of Lan Xang Kingdom and affect to Buddhism maintenance. Later, the temples and arts were restored to reduce the anti-French movement of Lao people. Until, the late of the era, Socialist concept and ideology came into Lao and caused the conflicts with old feudal system and took into the civil war era and lead to feudal system art work ignorance, destroyed or lost. In modern era, Lao people has realized importance of the arts as a heritage of Laos, particularly, candle holder and create new candle holder to reflect the belief in Buddhism and extend the value of the Buddhist art in Laos.

The role of candle holder in Lao PDR was found in Buddhism in the past it has served as a reflection of tools and measurement of area in ritual ceremonies. And it was 
believed that the creation of candle holder was exorcised. In the present, candle holder is also being tools in important Buddhist rituals and being valuable Lao Buddhist art. The role of candle holder in the past was found that Lao cultural society candle holder play a role as reflection of Lao society prosperity, nobility of religion nobility, temple and places contained candle holder and also faithfulness in Buddhism as well as communication tool in the political movement of Laos and became to a feudalist representative of the controversial socialist ideology. Current candle holder reflects Laos's prosperity, faithfulness in Buddhism under the cultural diversity and valuable Buddhist art as cultural heritage for people to jointly maintain.

\section{SUGGESTIONS}

Should have research on merit-making ceremony, rituals which can reflect beliefs related or connect with candles holder or candle in Lao PDR include patterns and symbolism of candle holder in other cities or close-area to compare patterns, symbolism and reflection of candle holder are related to the history of the feudal system transition.

\section{REFERENCES}

Ngaosivat, M. and P. Nghoasriwattana, 2010. Chao Anu (1767-1829) Lao People and Southeast Asia. 2nd Edn., Viangchan, Vientiane, Laos, .

Ponsri, S., 2002. Community Development Theories and Principles. Odeon Store, Bangkok, Thailand,

Pothisan, S., 2015. Lao History. 1st Edn., Khon Kaen Thuraphan, Khon Kaen, Thailand,

Rodboon, S., 2002. Lao Buddhist Art. 2nd Edn., Bangkok Saithan Press, Bangkok, Thailand,

Roland, B., 1967. Elements of Semiology Translated from the French. Hill and Wang, New York, USA.,.

Saenboon, T., 2012. The Study of Identity of Isan Handicraft in Wooden Buddhist Relics: Case Study in Ubon Ratchathani Province. Ubon Ratchathani University, Ubon Ratchathani, Thailand.

Srisuntisuk, S., 2007. Rural Sociology: Concept of Theories and Social Trends. Exponet Publisher, Bangkok, Thailand,

Srisuro, W., 1993. Sim Isan. Faculty of Architecture University of Khon Kaen, Khon Kaen, Thailand, ISBN: 9748903141. 